\title{
Multilocus sequence analysis of Ensifer and related taxa
}

Correspondence

Anne Willems

Anne.Willems@UGent.be

\section{INTRODUCTION}

The rhizobia are a large and diverse group of soil bacteria that are capable of root nodule formation and nitrogen fixation and exist in symbiosis with leguminous plants. In recent years, their classification has undergone major changes and revisions and several novel species have been described (for reviews see Young \& Haukka, 1996; Zakhia \& de Lajudie, 2001; Broughton, 2003; Sawada et al., 2003). The current classification of rhizobia, as for other bacterial groups, is strongly influenced by polyphasic classification, taking into account phenotypic characteristics as well as genetic characteristics (Vandamme et al., 1996), with 16S rRNA gene phylogeny providing the backbone of the

Abbreviations: AIC, Akaike Information Criterion; ILD, incongruencelength difference; ML, maximum-likelihood; MLSA, multilocus sequence analysis; MP, maximum-parsimony; NJ, neighbour-joining.

The GenBank/EMBL/DDBJ accession numbers of new sequence data for dnaK, glnA, gltA, recA, thrC and 16S rRNA genes are given in Table 1. classification (Willems \& Collins, 1993; Young \& Haukka, 1996; Yanagi \& Yamasato, 1993; Young et al., 2001).

The rhizobia that belong to the Alphaproteobacteria include the genera Allorhizobium, Azorhizobium, Bradyrhizobium, Rhizobium, Mesorhizobium and Sinorhizobium (de Lajudie et al., 1994, 1998; Dreyfus et al., 1988; Jordan, 1982; Jarvis et al., 1997). In 16S rRNA gene-based phylogeny, Agrobacterium and Allorhizobium species are phylogenetically dispersed between Rhizobium species (Willems \& Collins, 1993; de Lajudie et al., 1998; Terefework et al., 1998; van Berkum et al., 2003). This observation, and the absence of clear phenotypic distinctions, has led to a proposal to merge these three genera into a single genus, Rhizobium (Young et al., 2001). However, this scheme has been challenged and is not generally accepted (Farrand et al., 2003). It rests largely on the $16 \mathrm{~S}$ rRNA gene phylogeny and the resulting genus Rhizobium would have the phylogenetic breadth of a bacterial family when neighbouring groups in the alphaproteobacterial 16S rRNA gene tree are considered (see Fig. 1 of Young et al., 2001). There is no single phylogenetic breadth for ranks above species (Brenner et al., 
2001); however, as pointed out by Konstantinidis \& Tiedje (2005), there is great comparative value in having taxonomic ranks that are comparable among lineages. Although this may not be achievable over the whole of prokaryote diversity, we can endeavour to establish broadly comparable groups within this part of the alphaproteobacterial tree, taking into account several genes and ultimately genomes (Konstantinidis \& Tiedje, 2005). We agree with Young et al. (2001) that Agrobacterium rhizogenes is best regarded as a member of Rhizobium, as it is always found to be closely related to the type species Rhizobium leguminosarum. However, at present we consider that uniting Agrobacterium, Allorhizobium and Rhizobium in a single genus (Young et al., 2001) is not a better solution. It is hoped that the taxonomy of these organisms will be resolved in the near future on the basis of a comprehensive analysis of additional markers (sequence and non-sequence). In this paper we use the Agrobacterium nomenclature, except for Rhizobium rhizogenes.

The 16S rRNA gene phylogeny was considered originally to be a good model for the so-called organismal phylogeny (Olsen \& Woese, 1993). In recent years, several studies have shown that the rRNA genes of rhizobia may occasionally undergo lateral transfer and genetic recombination, resulting in sequence mosaicism (Eardly et al., 1996, 2005; Sullivan et al., 1996; van Berkum et al., 2003; Vinuesa et al., 2005). These observations imply that the rhizobial rRNA gene phylogeny may not always accurately reflect prokaryotic phylogeny. A further disadvantage of $16 \mathrm{~S}$ rRNA gene phylogeny is that closely related species cannot always be distinguished because of the high level of sequence conservation. To overcome these limitations, proteinencoding genes, with a higher level of sequence divergence than rRNA genes, but sufficiently conserved to retain phylogenetic signal and to allow primers to be designed, have been suggested as alternative phylogenetic markers (Stackebrandt et al., 2002). Ideally, these would be single copy chromosomal genes that are universally distributed among prokaryotes. Examples of genes that are used frequently as molecular markers in various bacterial groups include recA (Eisen, 1995), gyrB (Yamamoto \& Harayama, 1995), rpoB (Mollet et al., 1998), rpoD (Yamamoto et al., 2000), groEL (Viale et al., 1994) and atpD (Ronner et al., 1991). Several housekeeping genes have already been used as alternative phylogenetic markers within rhizobia: for example, atpD and recA (Gaunt et al., 2001), glnA, $g \ln B$ (Turner \& Young, 2000; Wernegreen \& Riley, 1999), dnaK (Stepkowski et al., 2003) and gltA (Hernández-Lucas et al., 2004). Their phylogenies are not always in agreement with $16 \mathrm{~S}$ rRNA gene phylogeny. Indeed, trees based on single genes do not always reflect organismal phylogeny because of possible horizontal gene transfer or recombination, variable mutation rates and simple stochastic variation (Gevers et al., 2005; Coenye et al., 2005).

The ad hoc committee for re-evaluation of the species definition suggested that 'species should be identifiable by readily available methods (phenotypic, genomic)' and that one promising approach towards this end was the determination of a minimum of five housekeeping genes (Stackebrandt et al., 2002). Zeigler (2003) even suggested that sequence analysis of less than five suitable housekeeping genes might be sufficient for a reliable classification. Multilocus sequence analysis (MLSA), using the sequences of multiple protein-coding genes for genotypic characterization of a group of prokaryotes (Gevers et al., 2005), is used increasingly to study and elucidate taxonomic relationships between species (Wertz et al., 2003; Adékambi \& Drancourt, 2004; Christensen et al., 2004; Holmes et al., 2004; Naser et al., 2005; Thompson et al., 2005). MLSA is distinct from multilocus sequence typing (Maiden et al., 1998), a method that is used mostly in epidemiology to characterize strains at an infraspecific level by comparing allelic mismatches in housekeeping genes.

In this study we used Sinorhizobium (now renamed Ensifer, see below) as a model system to assess the use of MLSA for taxonomic purposes. This genus contains eleven species, most of which have been described in polyphasic studies: Sinorhizobium fredii, Sinorhizobium xinjiangense (Chen et al., 1988), Sinorhizobium meliloti, Sinorhizobium saheli, Sinorhizobium terangae (de Lajudie et al., 1994), Sinorhizobium medicae (Rome et al., 1996), Sinorhizobium arboris, Sinorhizobium kostiense (Nick et al., 1999), Sinorhizobium kummerowiae (Wei et al., 2002), 'Sinorhizobium morelense' (Wang et al., 2002) and Sinorhizobium americanum (Toledo et al., 2003). From 16S rRNA gene comparisons, it is apparent that the monotypic genus Ensifer is highly related to Sinorhizobium (Balkwill, 2005). This organism comprises predatory soil bacteria that were originally described in a separate genus as Ensifer adhaerens, based mainly on morphological and phenotypic characteristics (Casida, 1982). Phylogenetic analyses of 16S rRNA and $r e c A$ genes (Balkwill, 2005; Willems et al., 2003) indicate that Ensifer forms a well-supported cluster together with Sinorhizobium. From a polyphasic study, Willems et al. (2003) concluded that the genera Ensifer and Sinorhizobium can be considered as a single taxon and therefore should be merged. According to Rule 38 of the Bacteriological Code (Lapage et al., 1992), the oldest legitimate name, Ensifer Casida 1982, has priority over Sinorhizobium Chen et al. 1988. However, after discussion in the Subcommittee on the taxonomy of Rhizobium and Agrobacterium (Lindström \& Martínez-Romero, 2002) and in view of several arguments against abandoning the name Sinorhizobium, Willems et al. (2003) in a Request for an Opinion proposed that an exception might be made to Rule 38, allowing the transfer of Ensifer adhaerens to Sinorhizobium as Sinorhizobium adhaerens comb. nov. In a separate Request for an Opinion, Young (2003) proposed that the combination Sinorhizobium adhaerens is illegitimate because it contravenes Rules 23 and 24 of the Code and consequently proposed to transfer all Sinorhizobium species to the genus Ensifer. Recently, the Judicial Commission of the International Committee on Systematics of Prokaryotes ruled that the case for granting an exception to the Rules is too weak (P. De Vos, personal 
communication). We have therefore adopted the Ensifer nomenclature (Young, 2003).

In the present study, an MLSA approach was used to investigate the relationships of these bacteria by determining the phylogeny of the housekeeping genes recA (recombinase A), $g \ln A$ (glutamine synthetase type I), gltA (citrate synthase I) dnaK (heat-shock protein Hsp70) and thrC (threonine synthase). Their phylogenies were examined and compared to that of the 16S rRNA gene. In addition, several combined analyses were performed. The results and their possible taxonomic implications are discussed below.

\section{METHODS}

Strains and culture conditions. A total of 33 Ensifer strains was used in this study (Table 1): 26 strains representing all known former Sinorhizobium species (except for S. kummerowiae, for which we could not obtain a bona fide strain, and $S$. americanum, for which we could not obtain the complete set of genes) and seven strains representing the three genomovars (A, B and C) of E. adhaerens. In addition, 12 rhizobial strains were included as reference strains. These represent the different groups of the 16S rRNA gene phylogram of rhizobia and belong to the genera Bradyrhizobium, Rhizobium, Mesorhizobium and Agrobacterium. All bacterial strains were grown on yeast extract mannitol agar at $28^{\circ} \mathrm{C}$.

DNA preparation. Bacterial DNA was prepared using the alkaline lysis method as described previously (Baele et al., 2000).

Primers for amplification and sequencing. The following genes were studied: $r e c A, g \ln A, 16 \mathrm{~S}$ rRNA, gltA, dnaK and $t h r C$. To design primers for PCR amplification and sequencing of these genes, we used corresponding sequences derived from the genome sequences of related bacteria: Agrobacterium tumefaciens C58 (Wood et al., 2001; Goodner et al., 2001), S. meliloti 1021 (Galibert et al., 2001), Mesorhizobium loti MAFF 303099 (Kaneko et al., 2000), Brucella melitensis $16 \mathrm{M}^{\mathrm{T}}$ (DelVecchio et al., 2002) and Bradyrhizobium japonicum USDA 110 (Kaneko et al., 2002). The $d n a K, g \ln A, g l t A, r e c A$ and $t h r C$ sequences were compared using the program BioNumerics (Applied Maths) to identify conserved regions. The primers designed are listed in Table 2. Primers for the amplification of recA and $d n a K$ were obtained from the literature (Gaunt et al., 2001; Stepkowski et al., 2003).

PCR amplification and sequencing of the genes. PCR amplification was performed by means of a T-Gradient Thermocycler (Biometra) in $50 \mu \mathrm{l}$ reaction mixtures containing $2.5 \mu \mathrm{l}$ DNA extract, $10 \mathrm{mM}$ Tris/ $\mathrm{HCl} \mathrm{pH} 8.3,1.5 \mathrm{mM} \mathrm{MgCl}_{2}, 50 \mathrm{mM} \mathrm{KCl}$, $0.001 \%(\mathrm{w} / \mathrm{v})$ gelatin, $1 \mathrm{U}$ AmpliTaq DNA polymerase (Applied Biosystems), $200 \mu \mathrm{M}$ each deoxyribonucleotide and $50 \mathrm{ng}$ each primer. The temperature and cycling conditions used are given in Table 2. The PCR products and their concentration were verified by electrophoresis of $3 \mu \mathrm{l}$ product on a $1 \%$ agarose gel and staining with ethidium bromide. A molecular mass marker (Smartladder-Eurogentec) was included to estimate the length of the amplicons.

The amplified products were purified using a Qiaquick PCR purification kit (Qiagen). The purified DNA was sequenced using the dideoxynucleotide chain-termination method with fluorescent ddNTPs (Applied Biosystems) on an ABI Prism 3100 capillary sequencer, according to the manufacturer's instructions (Applied Biosystems). Consensus sequences were constructed using the AutoAssembler software (Applied Biosystems).
Phylogenetic data analysis. Nucleotide sequence alignments were made using CLUSTAL_X (Thompson et al., 1997), taking into account the corresponding amino acid alignments for protein-coding genes. To assess the influence of noise due to saturation of the third codon position, we performed incongruence-length difference (ILD) tests (Farris et al., 1994), as implemented in PAUP* version $4.0 \mathrm{~b} 10$ (Swofford, 2002), using the different codon positions as separate partitions in 1250 replications. As a further test to assess saturation, we used the index of substitution saturation described by Xia et al. (2003) as implemented in DAMBE version 4.2.13 (Xia \& Xie, 2001). The same set of strains was used for all genes and sequence data for Caulobacter crescentus CB15, extracted from the complete genome sequence (Nierman et al., 2001), were used as an outgroup. Neighbour-joining (NJ), maximum-parsimony (MP) and maximumlikelihood (ML) analyses were performed with PAUP*. NJ analyses were performed using the Kimura-2 correction and 1000 bootstrap replications; MP analyses were performed using the heuristic search option. For the 16S rRNA gene, this resulted in 46 best trees, which were reduced to five by repeating the analysis using the Goloboff-fit criterion ( $\mathrm{GK}=2$; Goloboff, 1993). For ML analyses, the optimal models of nucleotide substitution were estimated using the program MODELTEST 3.7 (Posada \& Crandall, 1998), using both hierarchical likelihood ratio tests and the Akaike Information Criterion (AIC). Using both options, the same model was obtained in all cases, except for the 16S rRNA gene and $d n a K$, where models obtained with AIC were used (Posada \& Buckley, 2004). The MP trees were used as starting trees for the heuristic search procedure. Bootstrap analyses were performed using 1000 replications of heuristic searches for MP and 100 replications for ML. The ILD test implemented in PAUP* and using 1250 replicates was used to assess incongruence between datasets. To assess particular hypotheses, the Shimodaira-Hasegawa test (Shimodaira \& Hasegawa, 1999) as implemented in PAUP* was used. The significance of differences in the likelihood scores was assessed by a bootstrap test with 1000 replications.

\section{RESULTS AND DISCUSSION}

We analysed comparatively the sequences of six genes (five housekeeping genes and the 16S rRNA gene) for 33 Ensifer strains and 12 representatives of related taxa (Table 1). We also included corresponding sequences retrieved from the complete genome sequences of Agrobacterium tumefaciens C58, Brucella melitensis $16 \mathrm{M}^{\mathrm{T}}$, Brucella suis $1330^{\mathrm{T}}, C$. crescentus CB15, Rhodopseudomonas palustris CGA009 and Bradyrhizobium japonicum USDA 110, available in GenBank/EMBL/DDBJ. The choice of genes was guided by the following requirements: single copy occurrence, relatively high degree of conservation (as established from the literature) and separate location on the main chromosome (as assessed from the complete genome of S. meliloti). Sequence alignments were inspected visually to identify positions with uncertain alignment to be omitted from further analyses. The lengths of the alignments used for further analysis were: $498 \mathrm{bp}$ for $\operatorname{rec} A, 975 \mathrm{bp}$ for $g \ln A$, $639 \mathrm{bp}$ for $g l t A, 285 \mathrm{bp}$ for $d n a K, 636 \mathrm{bp}$ for $t h r C$ and 1419 for the 16S rRNA gene. No parts of the sequences were omitted, except in the case of the 16S rRNA gene for the type strain of Rhizobium leguminosarum where, in two different positions, a single $\mathrm{C}$ residue was omitted because it was absent from all other taxa included in the alignment. 
Table 1. Strains used and GenBank/EMBL/DDBJ accession numbers

Accession numbers of new data are in bold.

\begin{tabular}{|c|c|c|c|c|c|c|c|}
\hline Name & 16S rRNA & recA & $g \ln A$ & dnaK & thrC & gltA & Source \\
\hline \multicolumn{8}{|l|}{ Ensifer adhaerens gv. A } \\
\hline LMG 9954 (=BR819) & AM181735 & AJ505599 & AM182970 & AM182112 & AM181721 & AM181647 & Leucaena leucocephala, Brazil \\
\hline LMG 10007 (=BR8606) & AM181734 & AJ505600 & AM182969 & AM182111 & AM181720 & AM181646 & Pithecellobium dulce, Brazil \\
\hline R-9451 (=HAMBI 1631) & AJ420774 & AJ505598 & AM182968 & AM182110 & AM181719 & AM181645 & Sesbania grandiflora, Sri Lanka \\
\hline $\begin{array}{l}\text { Ensifer adhaerens gv. B R-7457 } \\
(=5 \mathrm{D} 19)\end{array}$ & AJ420773 & AJ505597 & AM182967 & AM182109 & AM181718 & AM181644 & Medicago sativa, Spain \\
\hline \multicolumn{8}{|l|}{ Ensifer adhaerens gv. C } \\
\hline LMG $20216^{\mathrm{T}}\left(=\operatorname{ATCC} 33212^{\mathrm{T}}\right)$ & AM181733 & AJ505595 & AM182966 & AM182108 & AM181717 & AM181643 & Soil, central PA, USA \\
\hline R-14067 (=ATCC 33499) & AM181731 & AM182150 & AM182964 & AM182106 & AM181715 & AM181641 & Soil, central PA, USA \\
\hline LMG 20582 (=R-6387) & AJ420775 & AJ505596 & AM182965 & AM182107 & AM181716 & AM181642 & Agricultural soil, Pittem, Belgium \\
\hline \multicolumn{8}{|l|}{ Ensifer arboris } \\
\hline LMG $14919^{\mathrm{T}}\left(=\right.$ HAMBI $\left.1552^{\mathrm{T}}\right)$ & AM181744 & AM182130 & AM182944 & AM182086 & AM181695 & AM181621 & Prosopis chilensis, Kosti, Sudan \\
\hline LMG 14917 (=HAMBI 1396) & AM181752 & AM182131 & AM182945 & AM182087 & AM181696 & AM181622 & Prosopis chilensis, Kenya \\
\hline LMG $19223(=$ HAMBI 1704) & AM181738 & AM182129 & AM182943 & AM182085 & AM181694 & AM181620 & Acacia senegal, Khartoum, Sudan \\
\hline \multicolumn{8}{|l|}{ Ensifer fredii } \\
\hline LMG $6217^{\mathrm{T}}\left(=\right.$ USDA $\left.205^{\mathrm{T}}\right)$ & $\mathrm{X} 67231$ & AM182145 & AM182959 & AM182101 & AM181710 & AM181636 & Glycine max, Honan, China \\
\hline LMG 8317 (=USDA 191) & X77123 & AM182144 & AM182958 & AM182100 & AM181709 & AM181635 & Soil, Shanghai, China \\
\hline LMG 6218 (=USDA 206) & AM181740 & AM182146 & AM182960 & AM182102 & AM181711 & AM181637 & Glycine max, Honan, China \\
\hline LMG 6216 (=LMG 8317) & AM181749 & AM182147 & AM182961 & AM182103 & AM181712 & AM181638 & Soil, Shanghai, China \\
\hline \multicolumn{8}{|l|}{ Ensifer kostiensis } \\
\hline LMG $19227^{\mathrm{T}}\left(=\right.$ HAMBI $\left.1489^{\mathrm{T}}\right)$ & AM181748 & AM182142 & AM182956 & AM182098 & AM181707 & AM181633 & Acacia senegal, Kosti, Sudan \\
\hline LMG 14911 (=HAMBI 1502) & AM181750 & AM182143 & AM182957 & AM182099 & AM181708 & AM181634 & Acacia senegal, Tendelti, Sudan \\
\hline LMG 19225 (=HAMBI 1484) & AM181747 & AM182141 & AM182955 & AM182097 & AM181706 & AM181632 & Prosopis chilensis, Kosti, Sudan \\
\hline \multicolumn{8}{|l|}{ Ensifer medicae } \\
\hline LMG $19920^{\mathrm{T}}\left(=\mathrm{A} 321^{\mathrm{T}}\right)$ & L39882 & AM182135 & AM182949 & AM182091 & AM181700 & AM181626 & Medicago truncatula, Aude, France \\
\hline LMG $19921(=\mathrm{R}-481)$ & AM181754 & AM182136 & AM182950 & AM182092 & AM181701 & AM181627 & Medicago truncatula \\
\hline LMG $18864(=$ HAMBI 1809$)$ & AM181746 & AM182137 & AM182951 & AM182093 & AM181702 & AM181628 & Medicago truncatula, Syria \\
\hline \multicolumn{8}{|l|}{ Ensifer meliloti } \\
\hline LMG $6133^{\mathrm{T}}\left(=\mathrm{NZP} 4027^{\mathrm{T}}\right)$ & $\mathrm{X} 67222$ & AM182133 & AM182947 & AM182089 & AM181698 & AM181624 & Medicago sativa, VA, USA \\
\hline LMG 4289 (=INRA 2011) & AM181751 & AM182134 & AM182948 & AM182090 & AM181699 & AM181625 & Medicago sativa \\
\hline LMG 6130 (=NZP 4009) & AM181739 & AM182132 & AM182946 & AM182088 & AM181697 & AM181623 & Medicago sativa, Australia \\
\hline $\begin{array}{l}\text { 'Sinorhizobium morelense' LMG } \\
21331 \text { (=CFN E1007) }\end{array}$ & AM181737 & AJ505601 & AM182971 & AM182113 & AM181722 & AM181648 & $\begin{array}{l}\text { Leucaena leucocephala } \mathrm{cv} \text {. } \\
\text { Cunningham in cultivated soils }\end{array}$ \\
\hline \multicolumn{8}{|l|}{ Ensifer saheli } \\
\hline LMG $7837^{\mathrm{T}}\left(=\right.$ ORS $\left.609^{\mathrm{T}}\right)$ & $\mathrm{X} 68390$ & AM182138 & AM182952 & AM182094 & AM181703 & AM181629 & Sesbania cannabina, Dakar, Senegal \\
\hline LMG $11864(=$ ORS 600) & AM181753 & AM182140 & AM182954 & AM182096 & AM181705 & AM181631 & Sesbania pachycarpa, Senegal \\
\hline LMG $8310(=$ ORS 611) & AM181742 & AM182139 & AM182953 & AM182095 & AM181704 & AM181630 & Sesbania grandiflora, Dakar, Senegal \\
\hline \multicolumn{8}{|l|}{ Ensifer terangae } \\
\hline LMG $7834^{\mathrm{T}}\left(=\right.$ ORS $\left.1009^{\mathrm{T}}\right)$ & X68388 & AM182153 & AM182974 & AM182116 & AM181725 & AM181651 & Acacia laeta, Dakar, Senegal \\
\hline LMG 11859 (= ORS 52) & AM181743 & AM182154 & AM182975 & AM182117 & AM181726 & AM181652 & Sesbania rostrata, Senegal \\
\hline LMG $6464(=$ ORS 51) & AM181741 & AM182152 & AM182973 & AM182115 & AM181724 & AM181650 & Sesbania rostrata, Dakar, Senegal \\
\hline \multicolumn{8}{|l|}{ Ensifer xinjiangensis } \\
\hline LMG $17930^{\mathrm{T}}\left(=\right.$ CCBAU $\left.110^{\mathrm{T}}\right)$ & AM181732 & AM182148 & AM182962 & AM182104 & AM181713 & AM181639 & Glycine max, Xinjiang, China \\
\hline R-16438 ( =CCBAU 83834) & AM181736 & AM182149 & AM182963 & AM182105 & AM181714 & AM181640 & - \\
\hline Ensifer sp. LMG $20571(=\mathrm{R}-4955)^{*}$ & AJ420776 & AM182151 & AM182972 & AM182114 & AM181723 & AM181649 & Agricultural soil, Pittem, Belgium \\
\hline $\begin{array}{l}\text { Mesorhizobium loti LMG } 6125^{\mathrm{T}} \\
\left(=\mathrm{NZP} 2213^{\mathrm{T}}\right)\end{array}$ & X67229 & AM182156 & AM182977 & AM182118 & AM181728 & AM181654 & $\begin{array}{l}\text { Lotus corniculatus var. } \\
\text { tenuifolium, New Zealand }\end{array}$ \\
\hline $\begin{array}{l}\text { Mesorhizobium mediterraneum } \\
\text { LMG } 17148^{\mathrm{T}}\left(=\mathrm{UPM}-\mathrm{Ca} 36^{\mathrm{T}}\right)\end{array}$ & AM181745 & AM182157 & AM182978 & AM182119 & AM181729 & AM181655 & Cicer arietinum L., Spain \\
\hline $\begin{array}{l}\text { Bradyrhizobium elkanii LMG } 6134^{\mathrm{T}} \\
\left(=\text { USDA } 76^{\mathrm{T}}\right)\end{array}$ & AF362942 & AM182155 & AM182976 & AJ431152 & AM181727 & AM181653 & Glycine max, USA \\
\hline $\begin{array}{l}\text { Bradyrhizobium japonicum LMG } \\
6138^{\mathrm{T}}\left(=\mathrm{NZP} 5549^{\mathrm{T}}\right)\end{array}$ & X66024 & AM182158 & AM182979 & AM182120 & AM181730 & AM181656 & Glycine max, Japan \\
\hline $\begin{array}{l}\text { Rhizobium galegae LMG } 6214^{\mathrm{T}} \\
\left(=\mathrm{HAMBI} 540^{\mathrm{T}}\right)\end{array}$ & X67226 & AM182127 & AM182941 & AM182083 & AM181692 & AM181618 & Galega orientalis, Finland \\
\hline $\begin{array}{l}\text { Rhizobium gallicum } \mathrm{R}-4387^{\mathrm{T}} \\
\left(=\mathrm{R} 602 \mathrm{sp}^{\mathrm{T}}\right)\end{array}$ & AM181756 & AM182124 & AM182938 & AM182080 & AM181689 & AM181615 & Phaseolus vulgaris, France \\
\hline $\begin{array}{l}\text { Rhizobium giardinii } \mathrm{R}-4385^{\mathrm{T}} \\
\left(=\mathrm{H} 152^{\mathrm{T}}\right)\end{array}$ & AM181755 & AM182123 & AM182937 & AM182079 & AM181688 & AM181614 & Phaseolus vulgaris, France \\
\hline $\begin{array}{l}\text { Rhizobium huautlense LMG } \\
18254^{\mathrm{T}}\left(=\mathrm{S}^{\mathrm{T}} 2^{\mathrm{T}}\right)\end{array}$ & AF025852 & AM182128 & AM182942 & AM182084 & AM181693 & AM181619 & $\begin{array}{l}\text { Sesbania herbacea, Sierra de } \\
\text { Huautla, Mexico }\end{array}$ \\
\hline $\begin{array}{l}\text { Rhizobium leguminosarum LMG } \\
14904^{\mathrm{T}}\left(=\text { ATCC } 10004^{\mathrm{T}}\right)\end{array}$ & AM181757 & AM182125 & AM182939 & AM182081 & AM181690 & AM181616 & Pisum sativum, IL, USA \\
\hline
\end{tabular}


Table 1. cont.

\begin{tabular}{|c|c|c|c|c|c|c|c|}
\hline Name & 16S rRNA & $\operatorname{rec} A$ & $g \ln A$ & dnaK & thrC & gltA & Source \\
\hline $\begin{array}{l}\text { Rhizobium rhizogenes LMG } 150^{\mathrm{T}} \\
\left(=\mathrm{ATCC} 11325^{\mathrm{T}}\right)\end{array}$ & AY945955 & AM182126 & AM182940 & AM182082 & AM181691 & AM181617 & - \\
\hline $\begin{array}{l}\text { Agrobacterium radiobacter } \mathrm{LMG} \\
140^{\mathrm{T}}\left(=\mathrm{ATCC} 19358^{\mathrm{T}}\right)\end{array}$ & AM181758 & AM182121 & AM182935 & AM182077 & AM181686 & AM181612 & - \\
\hline $\begin{array}{l}\text { Agrobacterium rubi LMG } 17935^{\mathrm{T}} \\
\left(=\mathrm{ATCC} 13335^{\mathrm{T}}\right)\end{array}$ & AM181759 & AM182122 & AM182936 & AM182078 & AM181687 & AM181613 & $\begin{array}{l}\text { Rubus ursinis var. } \\
\text { loganobaccus, USA }\end{array}$ \\
\hline
\end{tabular}

${ }^{\star}$ Strain LMG 20571 was previously assigned to 'S. morelense' (Willems et al., 2003).

\section{Individual gene analyses}

For each Ensifer species (or genomovar) studied, sequences of the same gene for the various strains included (two to four per species) were highly similar (ranging from 98.0-100\% for gltA to $98.7-100 \%$ for $g \ln A$; values for $16 \mathrm{~S}$ rRNA genes were 99.6-100\%). Initial NJ trees that included all strains revealed that, in all cases, strains belonging to a single species clustered very closely together. For this reason, the type strains only were selected for further analysis in order to reduce computing times (except for ' $S$. morelense' where both strains were included, E. adhaerens where the three genomovars were represented and B. japonicum where subgroups I and Ia were represented). Among Ensifer species, the sequence similarities of the same housekeeping genes were clearly lower, ranging from $79.5-94.2 \%$ for $t h r C$ to $87.5-96.9 \%$ for $g \ln A$ (for the $16 \mathrm{~S}$ rRNA genes values were in the range 97.9-99.8\%). For the calculation of these inter-species sequence similarity ranges, Ensifer xinjiangensis (two strains) was excluded because, in all comparisons, it was identical or very similar to Ensifer fredii [four strains; 99-100\% sequence similarity for all genes except gltA (98.3-100\%)], strongly suggesting that the two species are in fact synonymous. The clear gap between within-species and between-species sequence similarity values (Fig. 1) demonstrates the greater potential for species discrimination using protein-encoding housekeeping genes

Table 2. Oligonucleotide primers used and PCR cycling conditions

Primers given in bold were used for initial amplification.

\begin{tabular}{|c|c|c|c|}
\hline Primer & Position $^{*}$ & Sequence $5^{\prime}-3^{\prime}$ & PCR cycling \\
\hline glnA1142R & $1162-1142$ & TGGAKCTTGTTCTTGATGCCG & \multirow{2}{*}{$\begin{array}{l}10 \min 95^{\circ} \mathrm{C}, 2 \times\left(2 \min 94^{\circ} \mathrm{C}, 2 \min 62^{\circ} \mathrm{C}, 1 \min 72^{\circ} \mathrm{C}\right) \text {, } \\
32 \times\left(30 \mathrm{~s} 94^{\circ} \mathrm{C}, 1 \min 61^{\circ} \mathrm{C}, 1 \min 72^{\circ} \mathrm{C}\right), 10 \min 72^{\circ} \mathrm{C}\end{array}$} \\
\hline $\operatorname{gln} A 572 \mathrm{R}$ & $591-572$ & GCATYTCRGARCGCATGTCC & \\
\hline gltA428F & $428-446$ & CSGCCTTCTAYCAYGACTC & \multirow{2}{*}{$\begin{array}{r}5 \min 95^{\circ} \mathrm{C}, 3 \times\left(2 \min 94^{\circ} \mathrm{C}, 2 \min 53^{\circ} \mathrm{C}, 1 \min 72^{\circ} \mathrm{C}\right) \text {, } \\
30 \times\left(30 \mathrm{~s} 94^{\circ} \mathrm{C}, 1 \min 53^{\circ} \mathrm{C}, 1 \min 72^{\circ} \mathrm{C}\right), 5 \min 72^{\circ} \mathrm{C}\end{array}$} \\
\hline gltA667R & $683-667$ & GCRTGCAGGATGAANAT & \\
\hline thrC1231R & $1250-1231$ & GGRAATTTDGCCGGRTGSGC & \multirow{3}{*}{$\begin{array}{r}5 \min 95^{\circ} \mathrm{C}, 3 \times\left(2 \min 94^{\circ} \mathrm{C}, 2 \min 55^{\circ} \mathrm{C}, 1 \min 72^{\circ} \mathrm{C}\right) \text {, } \\
30 \times\left(30 \mathrm{~s} 94^{\circ} \mathrm{C}, 1 \min 55^{\circ} \mathrm{C}, 1 \min 72^{\circ} \mathrm{C}\right), 5 \min 72^{\circ} \mathrm{C}\end{array}$} \\
\hline thrC577F & $577-597$ & GGCAMKTTCGACGAYTGCCAG & \\
\hline thrC766F & $766-782$ & GGCAATTTCGGCGAYAT & \\
\hline $\operatorname{recA555R} \dagger$ & $555-530$ & CGRATCTGGTTGATGAAGATCACCAT & \multirow{3}{*}{$\begin{array}{l}5 \min 95^{\circ} \mathrm{C}, 32 \times\left(45 \mathrm{~s} 94^{\circ} \mathrm{C}, 1 \min 60^{\circ} \mathrm{C}, 1 \min 30 \mathrm{~s}\right. \\
\left.74^{\circ} \mathrm{C}\right), 5 \min 72^{\circ} \mathrm{C}\end{array}$} \\
\hline recA63F $\dagger$ & $63-85$ & ATCGAGCGGTCGTTCGGCAAGGG & \\
\hline recA504R $\dagger$ & $504-523$ & TTGCGCAGCGCCTGGCTCAT & \\
\hline dnaK1466F $\ddagger$ & $1466-1488$ & AAGGARCANCAGATCCGCATCCA & \multirow{2}{*}{$\begin{array}{l}1 \min 94^{\circ} \mathrm{C}, 35 \times\left(1 \min 94^{\circ} \mathrm{C}, 1 \min 64^{\circ} \mathrm{C}, 40 \mathrm{~s} 72^{\circ} \mathrm{C}\right) \text {, } \\
5 \min 72^{\circ} \mathrm{C}\end{array}$} \\
\hline dnaK1777R $\ddagger$ & $1777-1799$ & TASATSGCCTSRCCRAGCTTCAT & \\
\hline
\end{tabular}

${ }^{*}$ Position relative to the sequences taken from the complete genome of E. meliloti 1021 (Galibert et al., 2001).

$\dagger$ From Gaunt et al. (2001).

†From Stepkowski et al. (2003). 


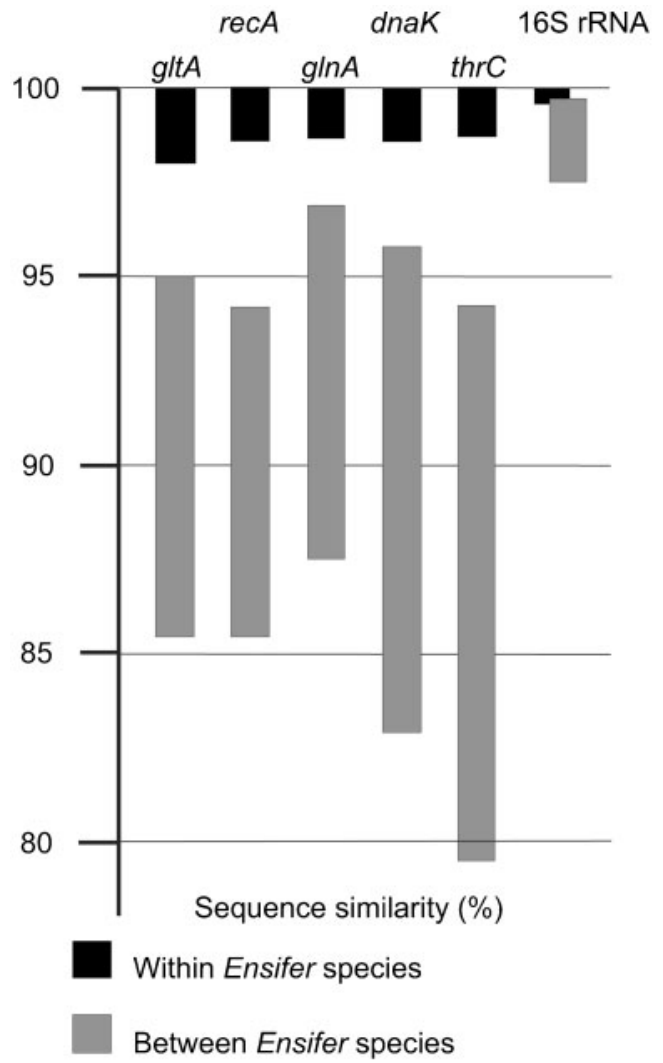

Fig. 1. Summary of the percentage sequence similarity results for six genes for Ensifer strains.

compared with $16 \mathrm{~S}$ rRNA genes, where there is in fact no gap. With any of the housekeeping genes used here, discrimination between the existing species and genomovars (except $E$. fredii and E. xinjiangensis) is clear and thus, for species identification purposes in Ensifer, these genes are superior to the $16 \mathrm{~S}$ rRNA gene.

According to ILD tests using first, second or third codon positions as separate partitions in pairwise comparisons, potential third codon saturation was found not to cause conflicting phylogenetic signals for most genes. For $t h r C$, the ILD test gave a $P$ value of 0.868 for the datasets containing only the first and the second positions, respectively, and 0.0376 for the datasets containing the first and third codon positions, respectively. However, based on the $P$ value of 0.5816 for a comparison of the partitions containing the second and the third codon positions, respectively, we decided to include the third position in further analyses. Furthermore, the indices of substitution saturation (Xia et al., 2003) did not indicate any significant saturation for any of the genes (data not shown).

Sequence characteristics are provided in Table 3 and demonstrate that the housekeeping genes are more informative than $16 \mathrm{~S}$ rRNA genes. g $\ln A$ was the largest gene fragment sequenced (975 bp) and contained the greatest number of parsimony-informative characters (388), representing $40 \%$ of sequenced positions. By comparison, thrC was one-third shorter in length, contained $60 \%$ informative characters and was the most information-rich of the genes studied. dnaK was the shortest fragment but, of its 285 positions, $51 \%$ were still parsimony informative.

For each of the genes, separate phylogenetic trees constructed using NJ, MP or ML methods gave similar groupings, although the precise branching pattern showed some variation (data not shown). For the housekeeping genes, we also prepared $\mathrm{NJ}$ trees of the amino acid sequences.

Table 3. Sequence information

IS, Invariable sites; No. nt, number of nucleotides; PI, parsimony-informative sites; VS, variable but parsimony-uninformative sites.

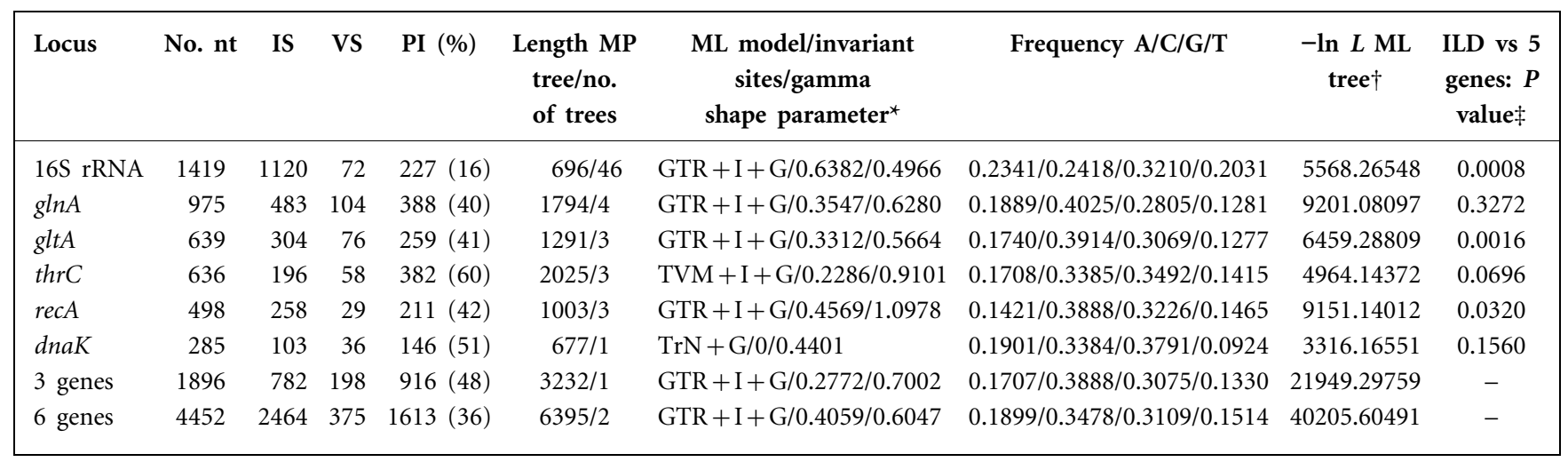

*Estimated using the AIC with the program mODELTEST. G, shape parameter of the gamma distribution; + G, indicates rate variation among sites is taken into account; GTR, General time-reversible model; I, proportion of invariable sites; $+\mathrm{I}+\mathrm{G}$, indicates invariable sites are included and rate variation among sites is taken into account; TrN, Tamura and Nei model; TVM, transversional model.

$\dagger L$, likelihood.

$\ddagger I L D$ test of this gene versus a partition consisting of a concatenation of the other five genes. 
However, these sequences were much less divergent and resulted in trees with relatively less clear separation of species and groups (data not shown). We therefore performed further analyses on the gene sequences. Most variation was observed for dnaK where some Rhizobium and Mesorhizobium species grouped among Ensifer species in the MP and ML trees. For $\operatorname{thr} C$, the three algorithms produced very similar branching patterns. To illustrate the differences observed between the gene phylogenies, the ML trees are shown in Fig. 2. Significant groupings in the different phylogenies are discussed below; however, it is clear that the different genes yield phylogenies that can differ to varying extents. This may be due to lateral gene transfer events, but also to the size of the dataset (in particular, the dnaK sequence is relatively short) and the taxa included. Bootstrap support for the observed groups was not always high in the ML trees, which generally have lower bootstrap values than corresponding NJ and MP trees (see below and Table 4).

It is clear that single housekeeping gene phylogenies should be interpreted as such and cannot be taken automatically to represent organismal phylogeny. To assess the latter, a combination of several genes seems indispensable, although it is unclear what the optimal number of genes should be.

\section{Concatenated sequence analyses}

One approach to combined data analysis is to combine only congruent data and to exclude data partitions with a significant level of incongruence, as they can introduce errors that may obscure reliable data and lead to erroneous topologies (Bull et al., 1993; Miyamoto \& Fitch, 1995).

The congruence of the different gene phylogenies was assessed using pairwise ILD tests. This revealed that $d n a K$, $\operatorname{thr} C$ and $g \ln A$ had compatible phylogenetic signals $(P$ values of $0.112-0.0936)$ and $r e c A$ also showed significant congruence with $\operatorname{gln} A(P=0.0640)$. For $d n a K$ this was surprising as visual comparison of gene trees (Fig. 2) shows a rather aberrant grouping. We assume that the tree represents a reduced picture of the information content and in this case highlights particular relationships that do not have significant bootstrap support. This may be related to the relatively short sequence used for this gene so that a strong spurious signal can dominate the information content. In the ILD test, this effect appeared to be levelled out to reveal the underlying signal, which in this case appears congruent with $t h r C$ and $g \ln A$.

Surprisingly, none of the housekeeping genes showed significant congruence with the $16 \mathrm{~S}$ rRNA gene $(P<0.01)$. This may be due to intragenic mosaicism, which has been reported previously to occur in these organisms (Eardly et al., 2005; Vinuesa et al., 2005). We divided the alignment into three partitions (1-357, 358-744 and 745-1419) that were reported previously to have different phylogenetic affiliations in Rhizobium galegae (Eardly et al., 2005). ILD tests were repeated for each of these partitions against each of the five housekeeping genes. No significant congruence was observed $(P<0.05$ in all combinations), indicating that mosaicism may be present in these partitions. To establish this with certainty, more detailed analyses of the alignments will be needed.

As a further test to detect aberrant phylogenetic signals, we performed an ILD test for each gene versus a partition comprising the remaining five genes (Table 3, last column). This test gives an indication of how well the phylogenetic signal in one gene is in-line with the phylogenetic signal of the other five genes taken together. Again, $g \ln A, d n a K$ and thrC gave $P$ values of greater than 0.05 , whereas recA yielded a $P$ value of 0.0320 and $16 \mathrm{~S}$ rRNA and $g l t A$ had $P$ values of less than 0.01 . The values for the $16 \mathrm{~S}$ rRNA gene and gltA could not be improved by eliminating one or two taxa potentially responsible for incongruence as deduced by visual inspection of the trees (data not shown). However, in the case of recA, exclusion of Rhizobium huautlense, Rhizobium galegae or both yielded $P$ values of 0.3024 , 0.0944 and 0.1064 , respectively, indicating that these species contribute strongly to the incongruence of the recA dataset. In view of the ILD test results, we concatenated the aligned sequences for $\operatorname{dnaK}, \operatorname{thr} C$ and $g \ln A$ only and obtained an alignment of 1896 nucleotides, comprising 782 invariable sites, 198 variable but parsimony-uninformative sites and $916(48 \%)$ parsimony-informative sites. MODELTEST was used to select the optimal substitution model for ML analysis (Table 3). NJ, MP and ML trees were now very similar and bootstrap support was generally higher (Fig. 3).

An alternative to the above approach of combining only congruent partitions is to calculate trees based on a concatenation of all six genes. Despite the possible presence of incongruent signals, this approach may improve the total resolution of the tree because the more conserved 16S rRNA gene may resolve other parts of the tree than the housekeeping genes. In many of the rhizobial groups, there is little divergence in the 16S rRNA gene between species. Therefore, in a combined tree, the 16S rRNA gene will not contribute much to branching patterns near the branch endings (here representing species level). The housekeeping genes we used, although still conserved, are more variable (Fig. 1) and will contribute more strongly to the branching patterns near the tips, whereas in the deeper parts of the tree their phylogenetic signal may be less clear because of noise from the higher number of substitutions. However, the effect of noise from individual partitions may be reduced in the larger complete dataset (Barrett et al., 1991; Kluge, 1989). The concatenated alignment of the six genes comprised 4452 positions, 2464 and 1613 (36\%) of which were constant and parsimony informative, respectively. MODELTEST was used to select the most suitable substitution model for ML analysis. Again, NJ, MP and ML trees were very similar and bootstrap support was high (Fig. 4). There was excellent agreement with the trees obtained based on the concatenation of $d n a K, \operatorname{thr} C$ and $g \ln A$. In this case, the combination of six genes with varying levels of congruence 
dnaK ML

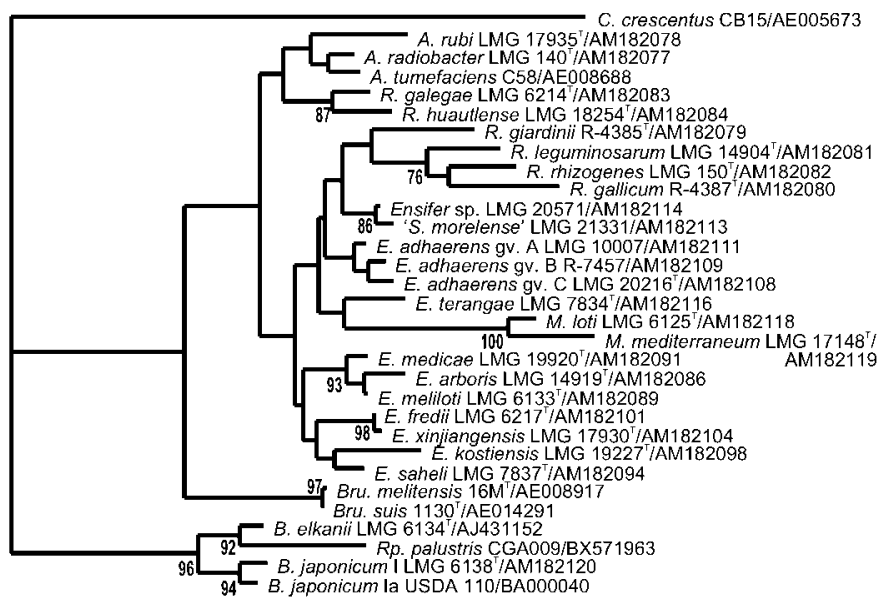

0.1

gltA ML

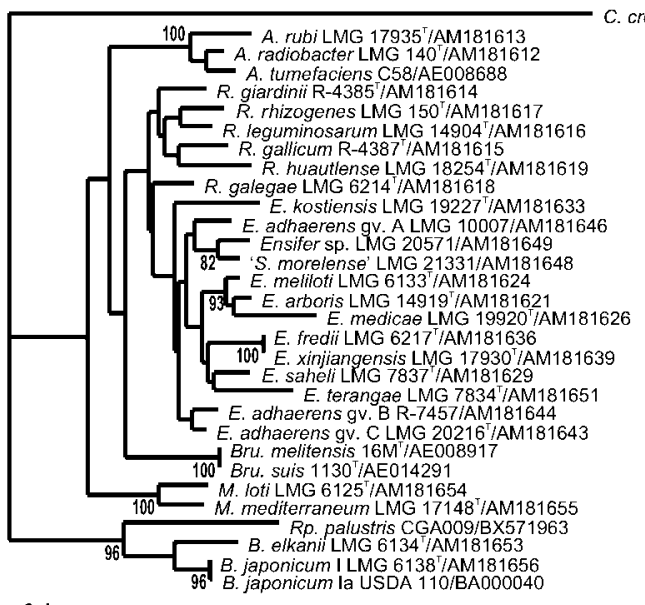

$\underline{0.1}$

thrC ML

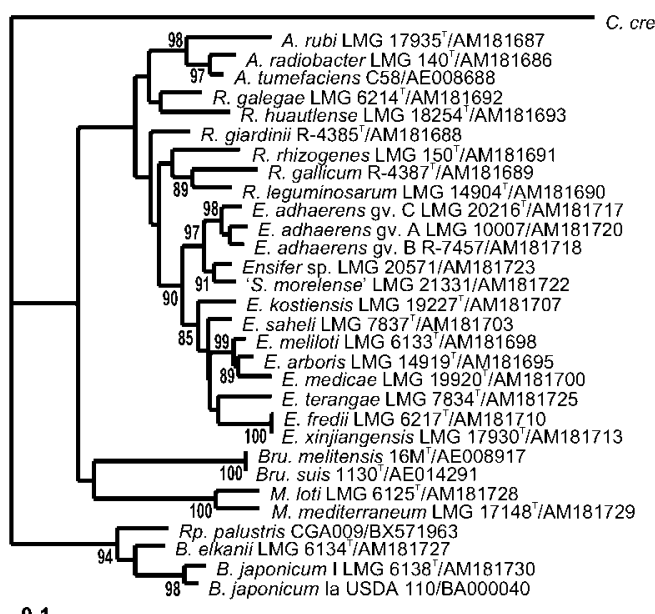

0.1
gInA ML

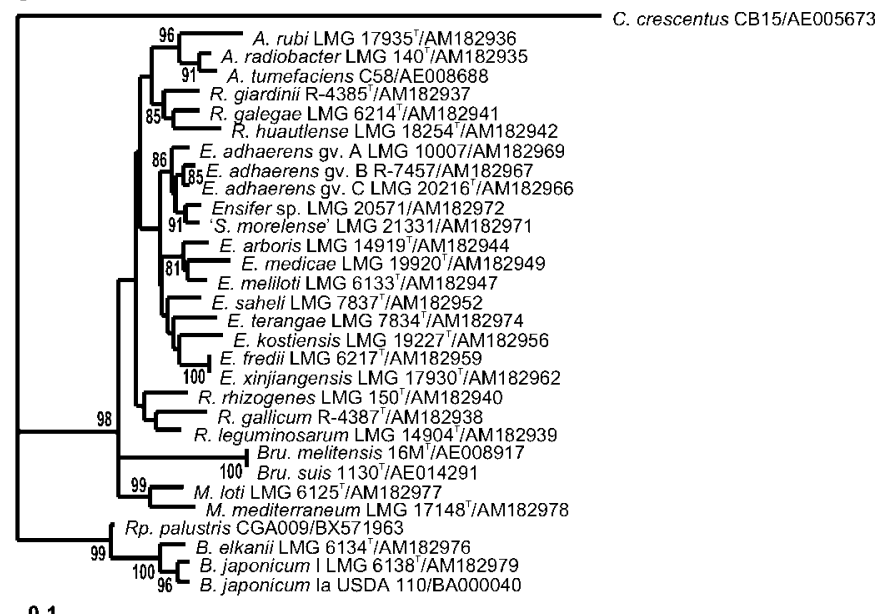

0.1

recA $\mathrm{ML}$



165 rRNA gene $M L$

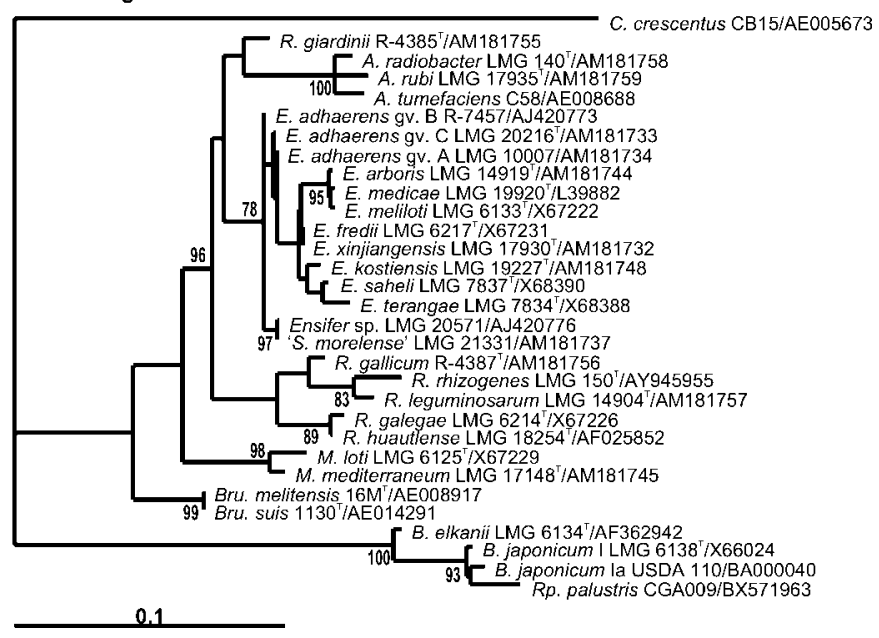


Table 4. Bootstrap support in the various analyses

10, $100 \%$ Bootstrap support; 9, 90-99\% bootstrap support; 8, 80-89\% bootstrap support.

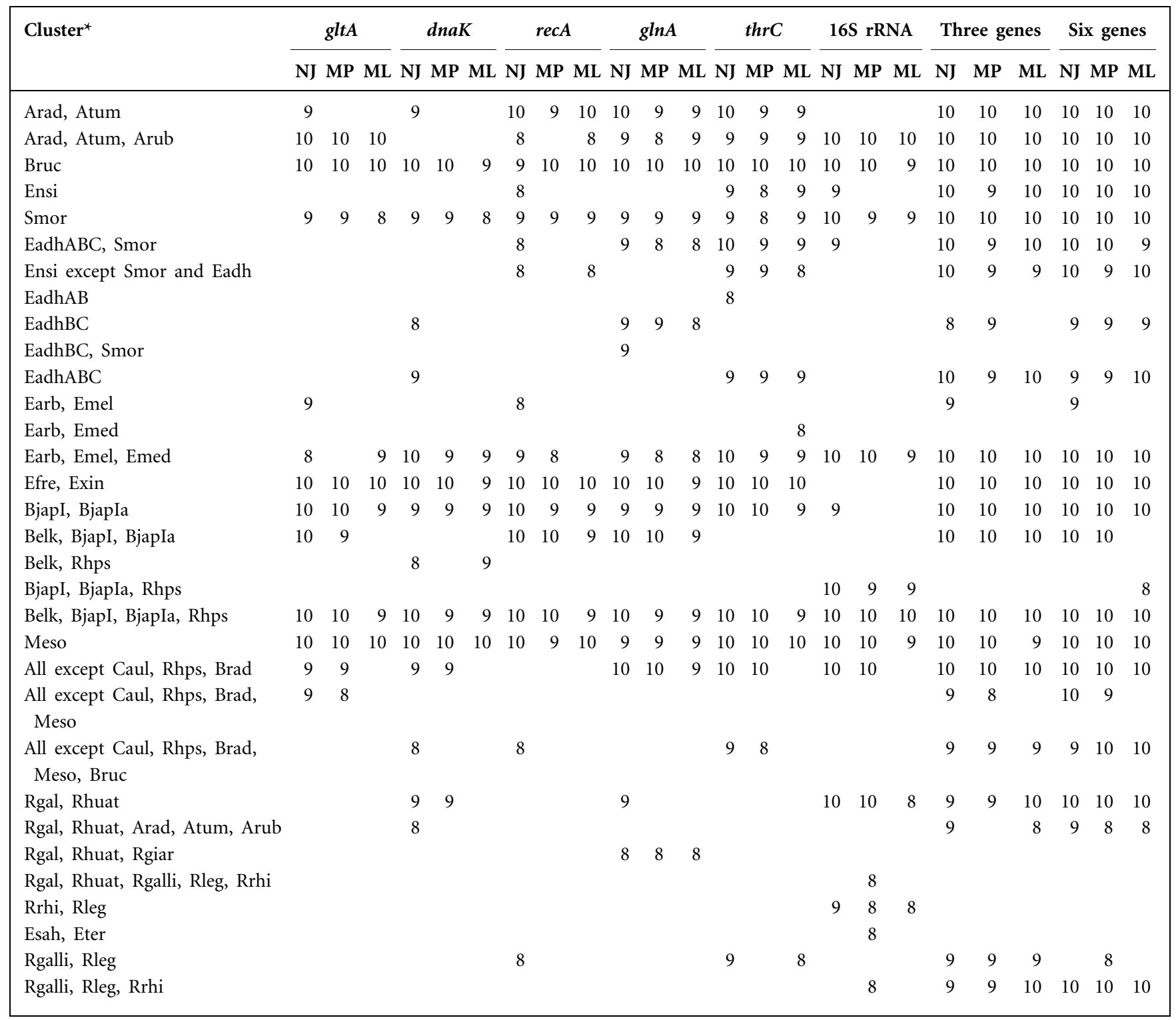

*Arad, Agrobacterium radiobacter; Arub, Agrobacterium rubi; Atum, Agrobacterium tumefaciens; Belk, Bradyrhizobium elkanii; BjapI, Bradyrhizobium japonicum I; BjapIa, Bradyrhizobium japonicum Ia; Brad, Bradyrhizobium; Bruc, Brucella; Caul, C. crescentus; EadhABC, E. adhaerens gv. A, B and C; Earb, E. arboris; Efre, E. fredii; Emed, E. medicae; Emel, E. meliloti; Ensi, Ensifer; Esah, E. saheli; Eter, E. terangae; Exin, E. xinjiangensis; Meso, Mesorhizobium; Rgal, Rhizobium galegae; Rgalli, Rhizobium gallicum; Rgiar, Rhizobium giardinii; Rhps, Rhodopseudomonas palustris; Rhuat, Rhizobium huautlense; Rleg, Rhizobium leguminosarum; Rrhi, Rhizobium rhizogenes; Smor, 'S. morelense' (2 strains).

appeared to level out aberrant signals that may be present in partly incongruent partitions, to yield trees that are highly similar, both in topology and bootstrap support, to those obtained by concatenating only congruent partitions (Fig. 3).

\section{Significantly grouped taxa}

Table 4 presents a simple but effective way of assessing the most strongly supported groups in all $24 \mathrm{NJ}$, MP and ML analyses. As was expected, the two reference strains of

Fig. 2. Phylogenetic trees based on six genes calculated using the $M L$ method. The complete genome sequence of $C$. crescentus strain CB15 was used as the outgroup. Bootstrap values of $75 \%$ or more (using 100 replicates) are indicated at branch points. Bars, 0.1 expected nucleotide substitutions per site. A., Agrobacterium; B., Bradyrhizobium; Bru., Brucella; R., Rhizobium; Rp., Rhodopseudomonas. 

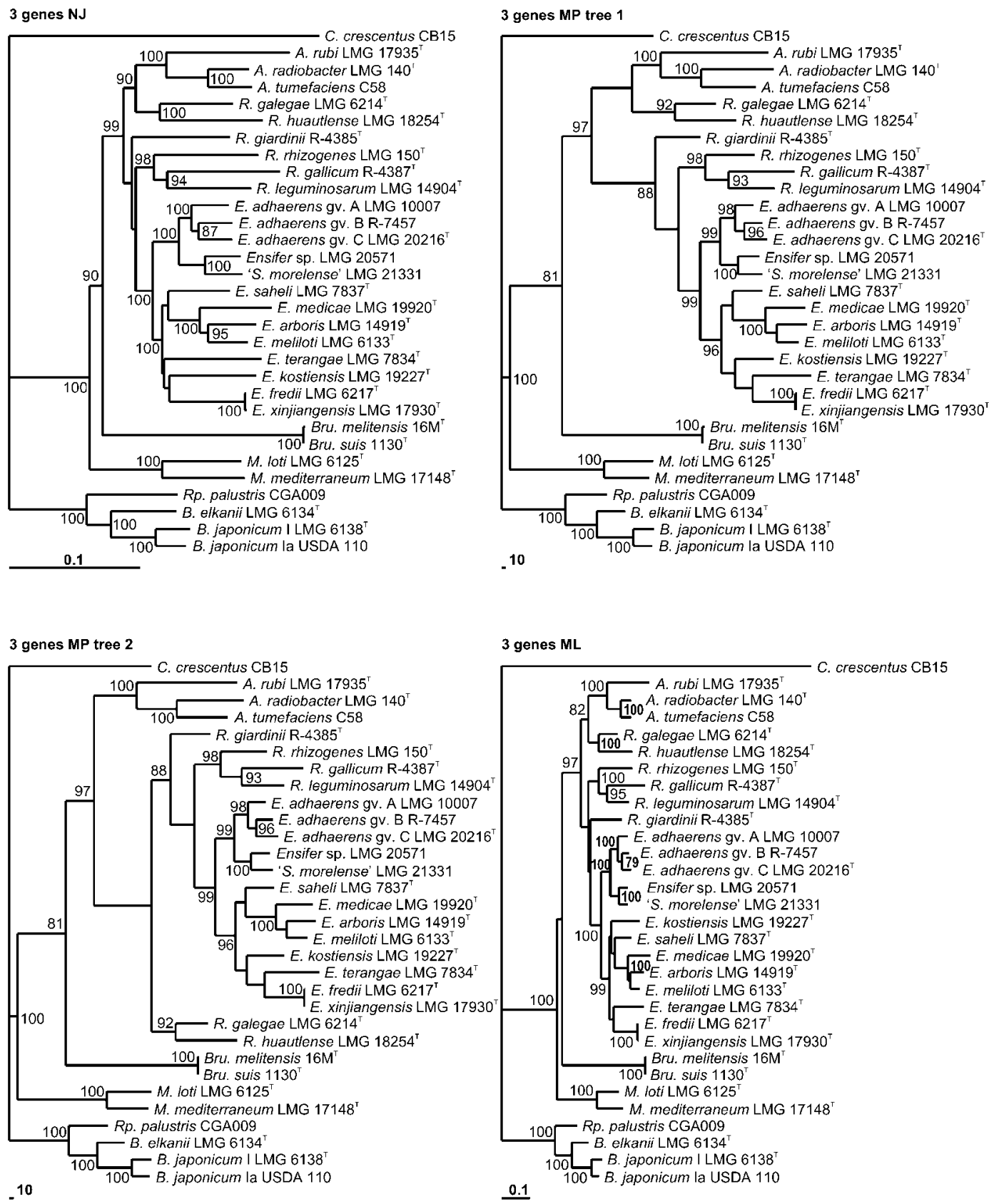

Fig. 3. Phylogenetic trees based on concatenated sequences of $d n a K, g \ln A$ and thrC, calculated using $N J, M P$ and $M L$. Strains used are the same as in Fig. 2. Bootstrap values of $75 \%$ or more (using 1000 replicates for NJ and MP; 100 for ML) are indicated at branch points. Bars, 0.1 estimated nucleotide substitutions per site (NJ and $\mathrm{ML}$ ); 10 base changes between nodes (MP). A., Agrobacterium; B., Bradyrhizobium; Bru., Brucella; R., Rhizobium; Rp., Rhodopseudomonas.

Brucella and those of Mesorhizobium each grouped together always. Similarly, Rhodopseudomonas palustris always grouped with Bradyrhizobium species, peripheral to the Bradyrhizobium cluster in the recA, gltA, thrC and $g \ln A$ phylogenies and inside the Bradyrhizobium cluster according to $16 \mathrm{~S}$ rRNA and dnaK gene phylogenies. In the case of dnaK, Rhodopseudomonas palustris grouped closer to Bradyrhizobium elkanii whereas, according to the 16S rRNA gene phylogeny, the same species is closer to Bradyrhizobium japonicum groups I and Ia. Agrobacterium radiobacter, Agrobacterium tumefaciens and Agrobacterium rubi were grouped together with high bootstrap support in all analyses except the dnaK phylogeny. Rhizobium galegae and Rhizobium huautlense grouped together with high bootstrap support in the 16S rRNA gene and in the two combined phylogenies, whereas Rhizobium gallicum, 
6 genes NJ

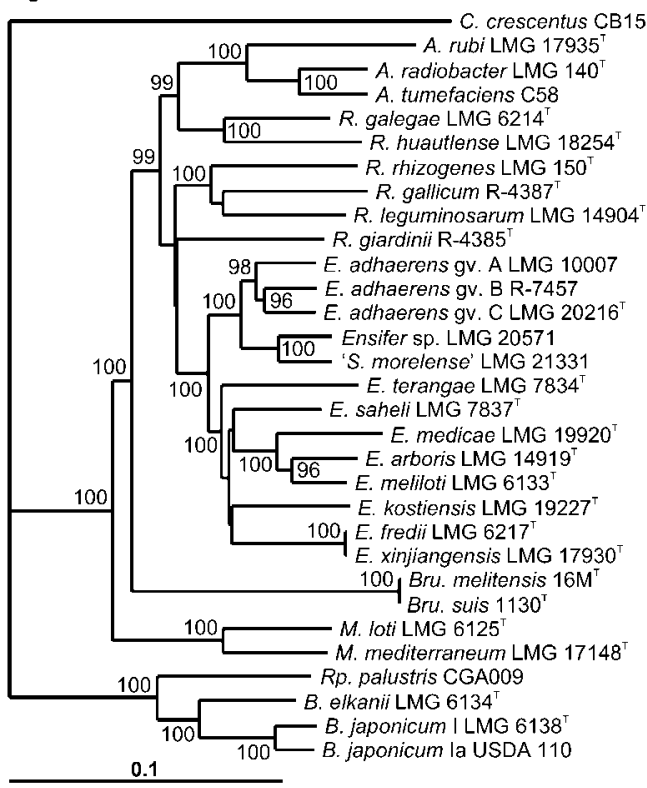

6 genes MP



6 genes ML

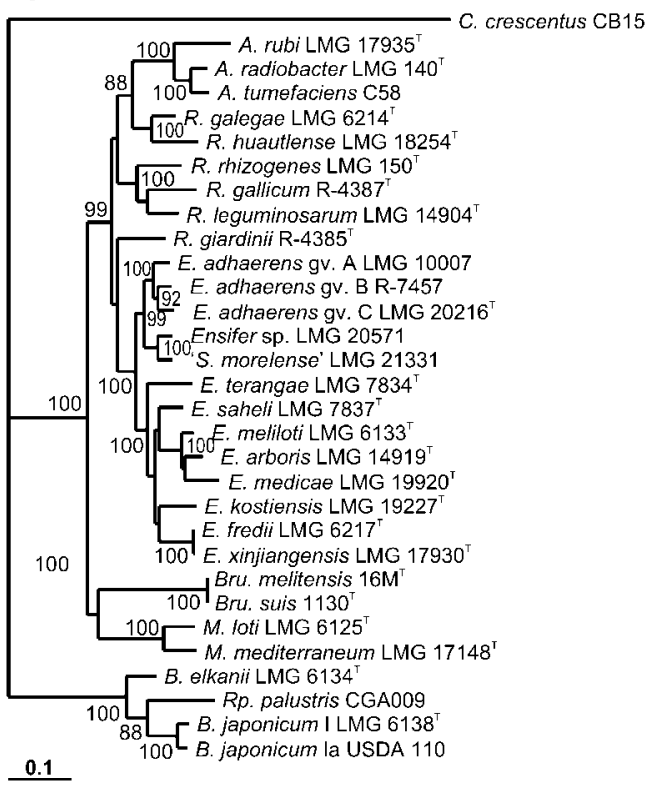

Fig. 4. Phylogenetic trees based on concatenated sequences of $d n a K, g \ln A$ and $\operatorname{th} r C, g / t A, r e c A$ and $16 S$ rRNA genes calculated using NJ, MP and ML. Strains used are the same as in Fig. 2. Bootstrap values of $75 \%$ or more (using 1000 replicates for NJ and MP; 100 for $\mathrm{ML}$ ) are indicated at branch points. Bars, 0.1 estimated nucleotide substitutions per site (NJ and $\mathrm{ML}) ; 100$ base changes between nodes (MP). A., Agrobacterium; B., Bradyrhizobium; Bru., Brucella; R., Rhizobium; Rp., Rhodopseudomonas.

Rhizobium leguminosarum and Rhizobium rhizogenes grouped together with significant support only in the combined analyses. In Ensifer, several groupings recurred, but not always with strong bootstrap support. A close relationship between E. meliloti, E. arboris and E. medicae was strongly supported. E. adhaerens grouped particularly with ' $S$. morelense'; bootstrap support for this relationship was strong in the $g \ln A$ and $t h r C$ phylogenies and the combined analyses. For ' $S$. morelense' we included the type strain and strain LMG 20571. The latter strain was previously assigned as representing ' $S$. morelense' on the basis of phenotypic and protein profile similarities (Willems et al., 2003). Our present data suggest that it may actually represent a separate but closely related genospecies. Our data do not support the proposal (Young, 2003) that 'S. morelense' is a later heterotypic synonym of E. adhaerens, but 
confirm that it represents a separate species, as has been established previously (Willems et al., 2003). The name of the species ' $S$. morelense' is considered to not be validly published because, at the time of publication, the type strain was not deposited in two publicly accessible culture collections in different countries (Euzéby \& Tindall, 2004). The type strain is now available from the BCCM/LMG (Belgium, http://bccm.belspo.be/about/lmg.php) and NBRC (Japan, http://www.nbrc.nite.go.jp/e/index.html) culture collections and thus fulfils the criteria for validation. However, because the name is the subject of a pending Request for an Opinion (Euzéby \& Tindall, 2004), 'S. morelense' cannot be transferred to the genus Ensifer before a ruling is published. The name of the species will only be established when an opinion from the Judicial Commission is approved and published. Therefore, at present we cannot adopt the Ensifer nomenclature for this species and the species name 'S. morelense' is used. It is evident from most trees that Ensifer adhaerens groups with the former Sinorhizobium species, although the bootstrap support for the whole group is strong only in the thrC phylogeny and in the two combined analyses of three and six genes. Our data thus support the proposal to unite the genera Ensifer and Sinorhizobium. The topologies of some trees suggest the possibility that E. adhaerens and 'S. morelense' together form a separate group that may be regarded as a sister taxon to the rest of Ensifer (the former Sinorhizobium). However, bootstrap support is high only in the thrC phylogeny and in the two combined analyses. We tested this hypothesis by using the Shimodaira-Hasegawa test (Shimodaira \& Hasegawa, 1999): for each gene, new ML trees (using the substitution models selected in MODELTEST) were constructed with the constraint that $E$. adhaerens and ' $S$. morelense' should form a group, the remaining Ensifer species should form a second group and that the two groups form a single cluster separate from the other taxa included. The likelihood of the constrained tree was compared with the likelihood of the original unconstrained ML tree using the ShimodairaHasegawa test. The test showed significant support for the hypothesis in all five housekeeping genes and for the $16 \mathrm{~S}$ rRNA gene (Table 5). Running the test for the concatenated

Table 5. Shimodaira-Hasegawa test

\begin{tabular}{|lcl|}
\hline Gene & $\boldsymbol{\Delta}-\ln \mathbf{L}^{*}$ & $\boldsymbol{P}$ \\
\hline 16S rRNA & 6.64264 & 0.1257 \\
glnA & 2.77208 & 0.3926 \\
gltA & 4.36147 & 0.3855 \\
thrC & 0 & 1 \\
recA & 2.05614 & 0.2005 \\
dnaK & 6.46891 & 0.2865 \\
dnaK $+\operatorname{thr} C+\mathrm{g} \ln A$ & 0 & 1 \\
Six genes & 15.01006 & 0.1454 \\
\hline
\end{tabular}

${ }^{\star} L$, likelihood. dataset of $d n a K, g \ln A$ and $\operatorname{thr} C$ and for the concatenation of the six genes yielded $P$ values of 1 and 0.1454 , respectively.

\section{Taxonomic conclusions}

An important observation from our data is that, according to ILD tests, the phylogenetic signal of the $16 \mathrm{~S}$ rRNA gene is not congruent with that of the five housekeeping genes used. This is in line with reports of possible recombination events among 16S rRNA genes of rhizobia (Eardly et al., 1996; van Berkum et al., 2003; Vinuesa et al., 2005). Taken together, these observations indicate that, at least in this group, $16 \mathrm{~S}$ rRNA gene data should be interpreted with caution and should always be compared with data from other genes so as to minimize the impact of possible recombination events when assessing phylogenetic relationships for taxonomic purposes.

The new data presented here confirm the close relationship between Ensifer and the former genus Sinorhizobium and provide supporting evidence for uniting the two genera, as proposed by Young (2003). An alternative scenario in which Ensifer would be restricted to E. adhaerens and 'S. morelense' and the genus Sinorhizobium maintained for the other Ensifer species had some support as apparent from the Shimodaira-Hasegawa test and analyses of concatenated sequences, but little support from the individual gene analyses. Furthermore, redefining genera in this group would require additional biological data. We conclude that, from the present evidence of six genes, classification as a single genus Ensifer is most appropriate.

\section{ACKNOWLEDGEMENTS}

This work was performed in the framework of project QLK3-CT-200202097 funded by the Commission of the European Communities and project G.0156.02 funded by the Fund for Scientific Research Flanders. A. W. is grateful for a postdoctoral fellowship from the Fund for Scientific Research - Flanders. We thank Olivier De Clerck for helpful discussions on phylogenetic analyses.

\section{REFERENCES}

Adékambi, T. \& Drancourt, M. (2004). Dissection of phylogenetic relationships among 19 rapidly growing Mycobacterium species by $16 \mathrm{~S}$ rRNA, hsp65, sodA, recA and $r p o B$ gene sequencing. Int J Syst Evol Microbiol 54, 2095-2105.

Baele, M., Baele, P., Vaneechoutte, M., Storms, V., Butaye, P., Devriese, L. A., Verschraegen, G., Gillis, M. \& Haesebrouck, F. (2000). Application of tRNA intergenic spacer PCR for identification of Enterococcus species. J Clin Microbiol 38, 4201-4207.

Balkwill, D. L. (2005). Genus VI. Ensifer Casida 1982, 343 ${ }^{\mathrm{VP}}$. In Bergey's Manual of Systematic Bacteriology, 2nd edn., vol. 2, part C, pp. 354-358. Edited by D. J. Brenner, N. R. Krieg, J. T. Staley \& G. M. Garrity. NY: Springer.

Barrett, M., Donoghue, M. J. \& Sober, E. (1991). Against consensus. Syst Zool 40, 486-493.

Brenner, D. J., Staley, J. T. \& Krieg, N. R. (2001). Classification of procaryotic organisms and the concept of bacterial speciation. In Bergey's Manual of Systematic Bacteriology, 2nd edn, vol. 1, pp. 
27-31. Edited by D. R. Boone, R. W. Castenholz \& G. M. Garrity. NY: Springer.

Broughton, W. J. (2003). Roses by other names: taxonomy of the Rhizobiaceae. J Bacteriol 185, 2975-2979.

Bull, J. J., Huelsenbeck, J., Cunningham, C. W., Swofford, D. L. \& Waddell, P. J. (1993). Partitioning and combining data in phylogenetic analyses. Syst Biol 42, 384-397.

Casida, L. E., Jr (1982). Ensifer adhaerens gen. nov., sp. nov.: a bacterial predator of bacteria in soil. Int J Syst Bacteriol 32, 339-345.

Chen, W. X., Yan, G. H. \& Li, J. L. (1988). Numerical taxonomic study of fast-growing soybean rhizobia and a proposal that Rhizobium fredii be assigned to Sinorhizobium gen. nov. Int J Syst Bacteriol 38, 392-397.

Christensen, H., Kuhnert, P., Olsen, J. E. \& Bisgaard, M. (2004). Comparative phylogenies of the housekeeping genes atpD, infB and $r p o B$ and the 16S rRNA gene within the Pasteurellaceae. Int J Syst Evol Microbiol 54, 1601-1609.

Coenye, T., Gevers, D., Van de Peer, Y., Vandamme, P. \& Swings, J. (2005). Towards a prokaryotic genomic taxonomy. FEMS Microbiol Rev 29, 147-167.

de Lajudie, P., Willems, A., Pot, B., Dewettinck, D., Maestrojuan, G., Neyra, M., Collins, M. D., Dreyfus, B., Kersters, K. \& Gillis, M. (1994). Polyphasic taxonomy of rhizobia: emendation of the genus Sinorhizobium and description of Sinorhizobium meliloti comb. nov., Sinorhizobium saheli sp. nov., and Sinorhizobium teranga sp. nov. Int J Syst Bacteriol 44, 715-733.

de Lajudie, P., Fulele-Laurent, E., Willems, A., Torck, U., Coopman, R., Collins, M. D., Kersters, K., Dreyfus, B. \& Gillis, M. (1998). Allorhizobium undicola gen. nov., sp. nov., nitrogen-fixing bacteria that efficiently nodulate Neptunia natans in Senegal. Int J Syst Bacteriol 48, 1277-1290.

DelVecchio, V. G., Kapatral, V., Redkar, R. J., Patra, G., Mujer, C., Los, T., Ivanova, N., Anderson, I., Bhattacharyya, A. \& other authors (2002). The genome sequence of the facultative intracellular pathogen Brucella melitensis. Proc Natl Acad Sci U S A 99, 443-448.

Dreyfus, B., Garcia, J. L. \& Gillis, M. (1988). Characterization of Azorhizobium caulinodans gen. nov. sp. nov., a stem-nodulating nitrogen-fixing bacterium isolated from Sesbania rostrata. Int J Syst Bacteriol 38, 89-98.

Eardly, B. D., Wang, F.-S. \& Van Berkum, P. (1996). Corresponding 16S rRNA segments in Rhizobiaceae and Aeromonas yield discordant phylogenies. Plant Soil 186, 69-74.

Eardly, B. D., Nour, S. M., van Berkum, P. \& Selander, R. K. (2005). Rhizobial 16S rRNA and dnaK genes: mosaicism and the uncertain phylogenetic placement of Rhizobium galegae. Appl Environ Microbiol 71, 1328-1335.

Eisen, J. A. (1995). The RecA protein as a model molecule for molecular systematic studies of bacteria: comparison of trees of RecAs and 16S rRNAs from the same species. J Mol Evol 41, 1105-1123.

Euzéby, J. P. \& Tindall, B. J. (2004). Status of strains that contravene Rules 27(3) and 30 of the Bacteriological Code. Request for an Opinion. Int J Syst Evol Microbiol 54, 293-301.

Farrand, S. K., van Berkum, P. B. \& Oger, P. (2003). Agrobacterium is a definable genus of the family Rhizobiaceae. Int J Syst Evol Microbiol 53, 1681-1687.

Farris, J. S. M., Källersjö, M., Kluge, A. G. \& Bult, C. (1994). Testing significance of incongruence. Cladistics 10, 315-319.

Galibert, F., Finan, T. M., Long, S. R., Puhler, A., Abola, P., Ampe, F., Barloy-Hubler, F., Barnett, M. J., Becker, A. \& other authors (2001). The composite genome of the legume symbiont Sinorhizobium meliloti. Science 293, 668-672.
Gaunt, M. W., Turner, S. L., Rigottier-Gois, L., Lloyd-Macgilp, S. A. \& Young, J. P. W. (2001). Phylogenies of atpD and recA support the small subunit rRNA-based classification of rhizobia. Int J Syst Evol Microbiol 51, 2037-2048.

Gevers, D., Cohan, F. M., Lawrence, J. G., Spratt, B. G., Coenye, T., Feil, E. J., Stackebrandt, E., Van de Peer, Y., Vandamme, P. \& other authors (2005). Opinion: Re-evaluating prokaryotic species. Nature Rev Microbiol 3, 733-739.

Goloboff, P. A. (1993). Estimating character weights during tree search. Cladistics 9, 83-91.

Goodner, B., Hinkle, G., Gattung, S., Miller, N., Blanchard, M., Qurollo, B., Goldman, B. S., Cao, Y., Askenazi, M. \& other authors (2001). Genome sequence of the plant pathogen and biotechnology agent Agrobacterium tumefaciens C58. Science 294, 2323-2328.

Hernández-Lucas, I., Rogel-Hernández, M. A., Segovia, L., RojasJiménez, K. \& Martínez-Romero, E. (2004). Phylogenetic relationships of rhizobia based on citrate synthase gene sequences. Syst Appl Microbiol 27, 703-706.

Holmes, D. E., Nevin, K. P. \& Lovley, D. R. (2004). Comparison of $16 \mathrm{~S}$ rRNA, nifD, recA, gyrB, rpoB and fusA genes within the family Geobacteraceae fam. nov. Int J Syst Evol Microbiol 54, 1591-1599.

Jarvis, B. D. W., van Berkum, P., Chen, W. X., Nour, S. M., Fernandez, M. P., Cleyet-Marel, J. C. \& Gillis, M. (1997). Transfer of Rhizobium loti, Rhizobium huakuii, Rhizobium ciceri, Rhizobium mediterraneum, and Rhizobium tianshanense to Mesorhizobium gen. nov. Int J Syst Bacteriol 47, 895-898.

Jordan, D. C. (1982). Transfer of Rhizobium japonicum Buchanan 1980 to Bradyrhizobium gen. nov., a genus of slow-growing, root nodule bacteria from leguminous plants. Int J Syst Bacteriol 32, 136-139.

Kaneko, T., Nakamura, Y., Sato, S., Asamizu, E., Kato, T., Sasamoto, S., Watanabe, A., Idesawa, K., Ishikawa, A. \& other authors (2000). Complete genome structure of the nitrogen-fixing symbiotic bacterium Mesorhizobium loti. DNA Res 7, 331-338.

Kaneko, T., Nakamura, Y., Sato, S., Minamisawa, K., Uchiumi, T., Sasamoto, S., Watanabe, A., Idesawa, K., Iriguchi, M. \& other authors (2002). Complete genomic sequence of nitrogen-fixing symbiotic bacterium Bradyrhizobium japonicum USDA110. DNA Res 9, 189-197.

Kluge, A. G. (1989). A concern for evidence and phylogenetic hypothesis relationships among Epicrates (Boidae, Serpentes). Zyst Zool 38, 7-25.

Konstantinidis, K. T. \& Tiedje, J. M. (2005). Towards a genome-based taxonomy for prokaryotes. J Bacteriol 187, 6258-6264.

Lapage, S. P., Sneath, P. H. A., Lessel, E. F., Skerman, V. B. D., Seeliger, H. P. R. \& Clark, W. A. (editors) (1992). International Code of Nomenclature of Bacteria (1990 Revision). Bacteriological Code. Washington, DC: American Society for Microbiology.

Lindström, K. \& Martínez-Romero, M. E. (2002). International Committee on Systematics of Prokaryotes Subcommittee on the taxonomy of Agrobacterium and Rhizobium. Minutes of the meeting, 4 July 2001, Hamilton, Canada. Int J Syst Evol Microbiol 52, 2337.

Maiden, M. C., Bygraves, J. A., Feil, E., Morelli, G., Russell, J. E., Urwin, R., Zhang, Q., Zhou, J., Zurth, K. \& other authors (1998). Multilocus sequence typing: a portable approach to the identification of clones within populations of pathogenic microorganisms. Proc Natl Acad Sci U S A 95, 3140-3145.

Miyamoto, M. M. \& Fitch, W. M. (1995). Testing species phylogenies and phylogenetic methods with congruence. Syst Biol 44, 64-76.

Mollet, C., Drancourt, M. \& Raoult, D. (1998). Determination of Coxiella burnetii $r p o B$ sequence and its use for phylogenetic analysis. Gene 207, 97-103.

Naser, S. M., Thompson, F. L., Hoste, B., Gevers, D., Dawyndt, P., Vancanneyt, M. \& Swings, J. (2005). Application of multilocus 
sequence analysis (MLSA) for rapid identification of Enterococcus species based on rpoA and pheS genes. Microbiology 151, 21412150.

Nick, G., de Lajudie, P., Eardly, B. D., Suomalainen, S., Paulin, L., Zhang, X., Gillis, M. \& Lindström, K. (1999). Sinorhizobium arboris sp. nov. and Sinorhizobium kostiense sp. nov., isolated from leguminous trees in Sudan and Kenya. Int J Syst Bacteriol 49, 1359-1368.

Nierman, W. C., Feldblyum, T. V., Laub, M. T., Paulsen, I. T., Nelson, K. E., Eisen, J., Heidelberg, J. F., Alley, M. R. K., Ohta, N. \& other authors (2001). Complete genome sequence of Caulobacter crescentus. Proc Natl Acad Sci U S A 98, 4136-4141.

Olsen, G. J. \& Woese, C. R. (1993). Ribosomal RNA: a key to phylogeny. FASEB J 7, 113-123.

Posada, D. \& Buckley, T. R. (2004). Model selection and model averaging in phylogenetics: advantages of the Akaike Information Criterion and Bayesian approaches over likelihood ratio tests. Syst Biol 53, 793-808.

Posada, D. \& Crandall, K. A. (1998). MODELTEST: testing the model of DNA substitution. Bioinformatics 14, 817-818.

Rome, S., Fernandez, M. P., Brunel, B., Normand, P. \& Cleyet-Marel, J.-C. (1996). Sinorhizobium medicae sp. nov., isolated from annual Medicago spp. Int J Syst Bacteriol 46, 972-980.

Ronner, S., Liesack, W., Wolters, J. \& Stackebrandt, E. (1991). Cloning and sequencing of a large fragment of the AtpD-gene of Pirellula marina: a contribution to the phylogeny of Planctomycetales. Endocytob Cell Res 7, 219-229.

Sawada, H., Kuykendall, L. D. \& Young, J. M. (2003). Changing concepts in the systematics of bacterial nitrogen-fixing legume symbionts. J Gen Appl Microbiol 49, 155-179.

Shimodaira, H. \& Hasegawa, M. (1999). Multiple comparisons of log-likelihoods with applications to phylogenetic inference. Mol Biol Evol 16, 1114-1116.

Stackebrandt, E., Frederiksen, W., Garrity, G. M., Grimont, P. A. D., Kämpfer, P., Maiden, M. C. J., Nesme, X., Rosselló-Mora, R., Swings, J. \& other authors (2002). Report of the ad hoc committee for the re-evaluation of the species definition in bacteriology. Int J Syst Evol Microbiol 52, 1043-1047.

Stepkowski, T., Czaplinska, M., Miedzinska, K. \& Moulin, L. (2003). The variable part of the $d n a K$ gene as an alternative marker for phylogenetic studies of rhizobia and related alpha Proteobacteria. Syst Appl Microbiol 26, 483-494.

Sullivan, J. T., Eardly, B. D., van Berkum, P. \& Ronson, C. W. (1996). Four unnamed species of nonsymbiotic rhizobia isolated from the rhizosphere of Lotus corniculatus. Appl Environ Microbiol 62, 2818-2825.

Swofford, D. L. (2002). PAUP*: Phylogenetic Analysis Using Parsimony (*and other methods), version 4. Sunderland, MA: Sinauer Associates.

Terefework, Z., Nick, G., Suomalainen, S., Paulin, L. \& Lindström, K. (1998). Phylogeny of Rhizobium galegae with respect to other rhizobia and agrobacteria. Int J Syst Evol Microbiol 48, 349-356.

Thompson, J. D., Gibson, T. J., Plewniak, F., Jeanmougin, F. \& Higgins, D. G. (1997). The CLUSTAL_X windows interface: flexible strategies for multiple sequence alignment aided by quality analysis tools. Nucleic Acids Res 25, 4876-4882.

Thompson, F. L., Gevers, D., Thompson, C. C., Dawyndt, P., Naser, S., Hoste, B., Munn, C. B. \& Swings, J. (2005). Phylogeny and molecular identification of vibrios on the basis of multilocus sequence analysis. Appl Environ Microbiol 71, 5107-5115.

Toledo, I., Lloret, L. \& Martínez-Romero, E. (2003). Sinorhizobium americanus sp. nov., a new Sinorhizobium species nodulating native Acacia spp. in Mexico. Syst Appl Microbiol 26, 54-64.
Turner, S. L. \& Young, J. P. W. (2000). The glutamine synthetases of rhizobia: phylogenetics and evolutionary implications. Mol Biol Evol 17, 309-319.

van Berkum, P., Terefework, Z., Paulin, L., Suomalainen, S., Lindström, K. \& Eardly, B. D. (2003). Discordant phylogenies within the rrn loci of rhizobia. J Bacteriol 185, 2988-2998.

Vandamme, P., Pot, B., Gillis, M., de Vos, P., Kersters, K. \& Swings, J. (1996). Polyphasic taxonomy, a consensus approach to bacterial systematics. Microbiol Rev 60, 407-438.

Viale, A. M., Arakaki, A. K., Soncini, F. C. \& Ferreyra, R. G. (1994). Evolutionary relationships among eubacterial groups as inferred from GroEL (chaperonin) sequence comparisons. Int J Syst Bacteriol 44, 527-533.

Vinuesa, P., Silva, C., Lorite, M. J., Izaguirre-Mayoral, M. L., Bedmar, E. J. \& Martínez-Romero, E. (2005). Molecular systematics of rhizobia based on maximum likelihood and Bayesian phylogenies inferred from $r r s, a t p D, r e c A$ and nifH sequences, and their use in the classification of Sesbania microsymbionts from Venezuelan wetlands. Syst Appl Microbiol 28, 702-716.

Wang, E. T., Tan, Z. Y., Willems, A., Fernández-López, M., ReinholdHurek, B. \& Martínez-Romero, E. (2002). Sinorhizobium morelense sp. nov., a Leucaena leucocephala-associated bacterium that is highly resistant to multiple antibiotics. Int J Syst Evol Microbiol 52, 1687-1693.

Wei, G. H., Wang, E. T., Tan, Z. Y., Zhu, M. E. \& Chen, W. X. (2002). Rhizobium indigoferae sp. nov. and Sinorhizobium kummerowiae sp. nov., respectively isolated from Indigofera spp. and Kummerowia stipulacea. Int J Syst Evol Microbiol 52, 2231-2239.

Wernegreen, J. J. \& Riley, M. A. (1999). Comparison of the evolutionary dynamics of symbiotic and housekeeping loci: a case for the genetic coherence of rhizobial lineages. Mol Biol Evol 16, 98-113.

Wertz, J. E., Goldstone, C., Gordon, D. M. \& Riley, M. A. (2003). A molecular phylogeny of enteric bacteria and implications for a bacterial species concept. J Evol Biol 16, 1236-1248.

Willems, A. \& Collins, M. D. (1993). Phylogenetic analysis of rhizobia and agrobacteria based on $16 \mathrm{~S}$ rRNA gene sequences. Int $J$ Syst Bacteriol 43, 305-313.

Willems, A., Fernández-López, M., Muñoz-Adelantado, E., Goris, J. De Vos, P., Martínez-Romero, E., Toro, N. \& Gillis M. (2003). Description of new Ensifer strains from nodules and proposal to transfer Ensifer adhaerens Casida 1982 to Sinorhizobium as Sinorhizobium adhaerens comb. nov. Request for an opinion. Int J Syst Evol Microbiol 53, 1207-1217.

Wood, D. W., Setubal, J. C., Kaul, R., Monks, D. E., Kitajima, J. P., Okura, V. K., Zhou, Y., Chen, L., Wood, G. E. \& other authors (2001). The genome of the natural genetic engineer Agrobacterium tumefaciens C58. Science 294, 2317-2323.

Xia, X. \& Xie, Z. (2001). DAMBE: software package for data analysis in molecular biology and evolution. J Hered 92, 371-373.

Xia, X., Xie, Z., Salemi, M., Chen, L. \& Wang, Y. (2003). An index of substitution saturation and its application. Mol Phylogenet Evol 26, $1-7$.

Yanagi, M. \& Yamasato, K. (1993). Phylogenetic analysis of the family Rhizobiaceae and related bacteria by sequencing of $16 \mathrm{~S}$ rRNA gene using PCR and DNA sequencer. FEMS Microbiol Lett 107, 115-120.

Yamamoto, S. \& Harayama, S. (1995). PCR amplification and direct sequencing of $g y r B$ genes with universal primers and their application to the detection and taxonomic analysis of Pseudomonas putida strains. Appl Environ Microbiol 61, 1104-1109.

Yamamoto, S., Kasai, H., Arnold, D. L., Jackson, R. W., Vivian, A. \& Harayama, S. (2000). Phylogeny of the genus Pseudomonas: intrageneric structure reconstructed from the nucleotide sequences of gyrB and rpoD genes. Microbiology 146, 2385-2394. 
Young, J. M. (2003). The genus name Ensifer Casida 1982 takes priority over Sinorhizobium Chen et al. 1988, and Sinorhizobium morelense Wang et al. 2002 is a later synonym of Ensifer adhaerens Casida 1982. Is the combination 'Sinorhizobium adhaerens' (Casida 1982) Willems et al. 2003 legitimate? Request for an Opinion. Int J Syst Evol Microbiol 53, 2107-2110.

Young, J. M., Kuykendall, L. D., Martínez-Romero, E., Kerr, A. \& Sawada, H. (2001). A revision of Rhizobium Frank 1889, with an emended description of the genus, and the inclusion of all species of Agrobacterium Conn 1942 and Allorhizobium undicola de Lajudie et al. 1998 as new combinations: Rhizobium radiobacter, $R$. rhizogenes, R. rubi, R. undicola and R. vitis. Int J Syst Evol Microbiol 51, 89-103.

Young, J. P. W. \& Haukka, K. E. (1996). Diversity and phylogeny of rhizobia. New Phytol 133, 87-94.

Zakhia, F. \& de Lajudie, P. (2001). Taxonomy of rhizobia. Agronomie 21, 569-576.

Zeigler, D. R. (2003). Gene sequences useful for predicting relatedness of whole genomes in bacteria. Int J Syst Evol Microbiol 53, 1893-1900. 